\title{
Aromatase deficiency: a rare cause of maternal virilisation and ambiguous genitalia in neonates
}

\author{
Mahdi Alsaleem, Diana E Miller, Lina Saadeh, Indrajit Majumdar
}

Pediatric, University at Buffalo-The State University of New York, Buffalo, New York, USA

\section{Correspondence to} Dr Mahdi Alsaleem, dmahdialsaleem@hotmail.com

Accepted 8 June 2019
Check for updates

(C) BMJ Publishing Group Limited 2019. No commercial re-use. See rights and permissions. Published by BMJ.

\begin{tabular}{l}
\hline To cite: Alsaleem M, \\
Miller DE, Saadeh L, \\
et al. BMJ Case Rep \\
2019;12:e231267. \\
doi:10.1136/bcr-2019- \\
231267 \\
\hline
\end{tabular}

\section{DESCRIPTION}

We describe a full term infant born to a 28 -year-old mother. Pregnancy was uncomplicated except for maternal signs of virilisation: hoarseness of voice, excess facial hair and a significant nasal enlargement. Perinatal vitamins were the only medication taken by the mother during pregnancy. Family history is significant for consanguinity. In her previous two pregnancies, the mother had developed similar virilisation symptoms that resolved shortly after birth. The outcomes for these two pregnancies were healthy term male newborns with normal physical examinations. The infant was active at birth with stable vital signs and appropriate growth parameters; however, concerning physical examinations of the genitalia necessitated transfer to our tertiary centre for further evaluation. The admission examination was significant for an enlarged phallus, complete fusion of the labioscrotal folds, absence of vaginal opening and non-palpable gonads (Prader stage 3-4) as shown in figure 1 . Rest of the physical examination was within normal limits, and the baby had no limb abnormalities. Laboratory investigations on admission showed cord blood oestradiol level of $2120 \mathrm{pg} / \mathrm{mL}(9000-34000 \mathrm{pg} / \mathrm{mL})$, androstenedione was $24840 \mathrm{ng} / \mathrm{dL}(\mathrm{nl}<80 \mathrm{ng} / \mathrm{dL})$ and dehydroepiandrosterone sulfate DHEA-S of 1420 $\mathrm{mcg} / \mathrm{dL}(\mathrm{nl}<360 \mathrm{mcg} / \mathrm{dL})$. At 12 hours of life, infant's FSH (Follicle stimulating hormone) was $0.264 \mathrm{mIU} / \mathrm{mL}$ and $\mathrm{LH}$ (Luteinizing hormone) was $0.147 \mathrm{mIU} / \mathrm{mL}$, both within normal range and total testosterone was $90 \mathrm{ng} / \mathrm{dL}(16-44 \mathrm{ng} / \mathrm{dL})$. At 72 hours, infant's $17-\mathrm{OHP}$ was $24 \mathrm{ng} / \mathrm{dL}(\mathrm{nl}<78)$ and androstenedione was $52 \mathrm{ng} / \mathrm{dL}$ (days 1-7; 20-290 ng/dL).

Maternal labs drawn 6 hours' postpartum were notable for oestradiol of $2200 \mathrm{pg} / \mathrm{mL}$ (6137$3460 \mathrm{ng} / \mathrm{dL}$ ) and testosterone concentration was $1307 \mathrm{ng} / \mathrm{dL}(63-309 \mathrm{ng} / \mathrm{dL})$. On the fourth day postpartum, both maternal oestradiol and testosterone levels were $726 \mathrm{pg} / \mathrm{mL}$ and $599 \mathrm{ng} / \mathrm{dL}$, respectively. Electrolyte concentrations were stable during the

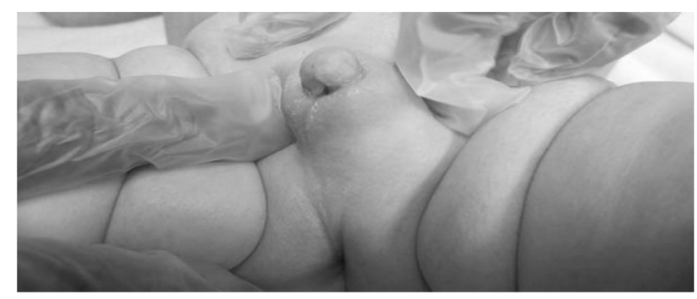

Figure 1 Ambigious genitalia due to placental aromatase enzyme deficiency.

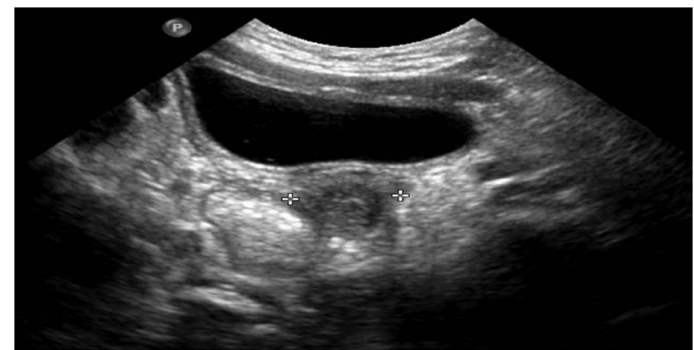

Figure 2 Pelvic ultrasonography image, revealing a uterine structure (between the asterisks) behind the bladder. Obtained by Mahdi Alsaleem.

2 weeks hospitalisation period. Chromosomal analysis resulted in 46, XX karyotype. Infant's pelvic ultrasonography revealed the presence of a uterine structure behind the bladder (figure 2). At the follow-up appointment at 2 months of age, maternal virilisation signs and symptoms resolved. Both maternal's and infant's androgen and oestradiol levels improved.

In the case presented, the mother manifested with signs of antenatal androgen excess, while the 46, $\mathrm{XX}$ infant had virilised external genitalia at birth. Both maternal and infant's symptoms improved significantly with time. The most likely explanation for these findings is the antenatal androgen excess associated with oestrogen deficiency from the inability to convert androgens into oestradiol in the fetus due to placental aromatase deficiency.

Aromatase deficiency was first described in Japan in 1991 in a newborn who presented with ambiguous genitalia, who later was found to have aromatase P450 gene defect. ${ }^{1}$ The incidence in neonates is unknown due to very few cases reported in the medical literature. ${ }^{2}$ The inheritance pattern is an autosomal recessive defect of the gene coding for aromatase enzyme located on chromosome 15 P21.1. Diagnosis can be missed if the genitalia abnormalities are subtle; in these

\section{Learning points}

- Maternal history is an essential part of the clinical evaluation for an infant with ambiguous genitalia.

- History of maternal virilisation during pregnancy should alert the clinicians to the possibility of aromatase enzyme deficiency diagnosis.

- If aromatase enzyme deficiency is suspected, workup should include serial measurement of the androgen and oestrogen levels of both the mother and the infant. 
cases, female patients present later in adulthood with primary amenorrhea and virilising symptoms. Both male and female patients with aromatase deficiency can present with tall stature, delayed bone age, osteoporosis and hyperglycaemia. ${ }^{34}$

Congenital adrenal hyperplasia $(\mathrm{CAH})$ is an essential differential. The priority of management in similar cases with ambiguous genitalia is to rule out $\mathrm{CAH}$ to prevent the life-threatening complication of adrenal crisis that can result in hypotension and salt wasting.

Contributors MA, DEM, LS and IM have contributed to the design, acquisition and analysis of data. All authors contributed to the drafting and revising this manuscript. MA, DEM, LS and IM approved this final version of this draft and agreed to be accountable for the article and to ensure that all questions regarding the accuracy or integrity of the article are investigated and resolved.
Funding The authors have not declared a specific grant for this research from any funding agency in the public, commercial or not-for-profit sectors.

Competing interests None declared.

Patient consent for publication Parental/Guardian consent obtained.

Provenance and peer review Not commissioned; externally peer reviewed.

\section{REFERENCES}

1 Shozu M, Akasofu K, Harada T, et al. A new cause of female pseudohermaphroditism: placental aromatase deficiency. J Clin Endocrinol Metab 1991;72:560-6.

2 Jones ME, Boon WC, McInnes K, et al. Recognizing rare disorders: aromatase deficiency. Nat Clin Pract Endocrinol Metab 2007:3:414-21.

3 Rochira V, Carani C. Aromatase deficiency in men: a clinical perspective. Nat Rev Endocrinol 2009:5:559-68.

4 Belgorosky A, Guercio G, Pepe C, et al. Genetic and clinical spectrum of aromatase deficiency in infancy, childhood and adolescence. Horm Res 2009:72:321-30.

Copyright 2019 BMJ Publishing Group. All rights reserved. For permission to reuse any of this content visit

https://www.bmj.com/company/products-services/rights-and-licensing/permissions/

BMJ Case Report Fellows may re-use this article for personal use and teaching without any further permission.

Become a Fellow of BMJ Case Reports today and you can:

- Submit as many cases as you like

- Enjoy fast sympathetic peer review and rapid publication of accepted articles

- Access all the published articles

Re-use any of the published material for personal use and teaching without further permission

\section{Customer Service}

If you have any further queries about your subscription, please contact our customer services team on +44 (0) 2071111105 or via email at support@bmj.com.

Visit casereports.bmj.com for more articles like this and to become a Fellow 